\title{
Complicating notions of violence: An embodied view of violence against women in Honduras
}

\begin{abstract}
Feminist geographic analysis has demonstrated that violence inflicted on women is embodied, experienced and personal and at the same time, linked to global socio-political and economic processes and patriarchal norms. Consequently, violence is a complex system instead of a norm located in certain places. In heavily militarised societies, patriarchal power regimes are even more prevalent because states' security strategies promote a masculinist understanding of protection as to who should be protected and by whom - and from what. This study draws on feminist geopolitical analysis and explores how feminist activists in Honduras experience and resist violence in their everyday lives. The research is grounded in interviews, focus-group discussions and participant observation with Honduran activists. The findings demonstrate that violence and its effects are firstly embedded in women's everyday lives through feelings of fear and unsafety on the streets, at the workplace and at home. Secondly, violence operates through structures and institutions such as the military and police, impunity for violence against women, and the juridical restriction of reproductive rights. Thirdly, the internationally financed war on drugs and 'development' projects contribute to violence - thus, there is a link between intimate experiences of violence and global economic and military powers that sustain violence. Activists therefore argue that, for their needs, the state's and international organisations' security approaches are inadequate. The paper weaves together feminist visions of collective self-care and discusses activists' strategies against violence. This study contributes to a growing feminist geographic scholarship linking women's bodily experiences with violence and responds to calls for complicating notions of violence.
\end{abstract}

Keywords: Violence, gender, militarism, feminist geopolitics, Honduras

Carmen: I think what happens a lot to all of us women is that we are facing many problems with this 'security' they are selling us; security based on repression, security based on militarisation, security based on closing us more and more inside our homes. And well, I think, as women, there is a lot of backlash regarding our autonomy and our bodies, of sexual and reproductive rights. I don't know...there are just so many things involved.

Feminist geographic scholars have spoken for more critical and progressive scholarship to analyse violence and (in)security beyond place (Mollett, 2017; Mountz \& Hyndman, 2006; Sundberg, 2014). They have criticised studies that define violence, particularly against women, primarily as individual, physical, and mostly identified after the fact (Bichsel, 2017; Cuomo, 2013). In addition, these studies often locate violence in 'other' regions, where violence is 'the norm' and thus women are not traumatised by it. However, feminist geographers have argued that women are not inherently prone to conflict and acceptance of violence (Bichsel, 2017; Fluri \& Piedalue, 2017). Focusing only on such local expressions of violence can thus result in overlooking global effects and the complexity of violence - or in other words, 'the many things involved.'

Feminist geographic studies have demonstrated that violence is based on a socio-spatial dialectic, which draws on historical-materialist understandings (Tyner \& Inwood, 2014). This notion draws on poststructuralist thought, which argues that what we take as the everyday, including our understanding of the 'reality' of violence, is itself

Citation: Jokela-Pansini, Maaret (2020) Environment and Planning C: Politics and Space, published online 16 February 2020. DOI: $10.1177 / 2399654420906833$

Author: Maaret Jokela-Pansini, Institute of Geography, University of Bern, Switzerland, maaret.jokela@giub.unibe.ch 
the outcome of the political (Foucault, 1978). In addition, the political and its societal structures are mainly based on patriarchal ideas of the state (Fluri \& Piedalue, 2017).

Feminist geographers have further argued that in conflicts, patriarchal power relations are even more prevalent because it has primarily been men who hold political and economic power, and conflicts have played out on women's bodies (Pain, 2015). Hence, an increasing number of studies in feminist geography have investigated interdependencies between militarism, government security strategies, spatialities of violence, and gender in conflict and militarised societies (Fluri, 2009; Hyndman, 2004; Pain, 2015; Slack, Martínez, Lee, \& Whiteford, 2016). These studies have found an increase in the past few years of the number of state militaries and military police forces in the world - aiming to 'protect' citizens. Scholars have criticised such militarist protection strategies and argued that by analysing civil and political spaces through the discourse of protection, we lose crucial insight into the multiple, daily embodied experiences of women with violence (Christian, Dowler, \& Cuomo, 2016).

This study draws on feminist geopolitics, which is firstly based on the idea that conflicts involve many scales, levels and actors besides states, which is why different forms of violence are structural and part of the same complex system (Fluri, 2009; Pain, 2015; Sjoberg \& Gentry, 2015; True, 2012). Secondly, feminist geopolitics analyses embodied epistemologies and subjects and develops a politics of security at the scale of the (civilian) body, rather than focusing on military protection (Hyndman, 2004). Thirdly, feminist geopolitical scholars have emphasised alternative ways to think about and build security. They have criticised how in prevalent discourses only certain people, institutions, places and activities have the agency to do politics and therefore, to provide security (Dowler $\&$ Sharp, 2014). For example, Pain (2009) has demonstrated how our understanding of security changes when we examine emotions about and with those who experience fear. Hyndman (2004) has stressed people's safety and well-being and Koopman (2011) has urged scholars to investigate grassroots security practices as 'altergeopolitics'. A common denominator in these studies is to think about daily, banal notions of security from below or rather, from all sides (Koopman, 2011).

Violence in Honduras is especially important to study because for almost a decade, international organisations have labelled Honduras as one the most dangerous countries in the world due to its high homicide rates (OHCHR, 2016; UNODC, 2013). Many international reports have presented violence in Honduras to be a local norm linked to gang violence, drug trafficking and militarisation. The government has bolstered its military forces in the name of national security and the region's 'war on drugs'. However, the state has also used military force against its citizens, including political opponents (Global Witness, 2015). An example since December 2018 concerns participants of the migrant caravans towards the United States, particularly women, who have reported violence as one of the main reasons for fleeing their country (Menjívar \& Walsh, 2018).

Thus, the state and the international community conceptualise violence in Honduras as self-evident and criminalise some acts of violence but not others. They mostly measure violence through crime such as homicide rates and thus, blur the boundaries between violence and crime (McIlwaine, 1999). As scholars have noted, violence has a geography (Blomley, 2003; Tyner, 2016). However, even most seemingly place-based expressions of violence such as the violence against women in Honduras are produced in broader relationships with space (Springer \& Le Billon, 2016). The task of researchers is thus to denaturalise or as I argue in this paper, to complicate such place-based notions of violence and regard 'the many things involved' that contribute to feminist activists' experiences with violence.

This study is based on a feminist geopolitical framework and aims to complicate notions of violence in Honduras and beyond. My analysis draws on three concepts of violence: 1) violence as a feeling, 2) violence constructed through structures and governmental institutions and 3) violence as both intimate and global. The study contributes to a growing feminist geographic scholarship investigating how violence and social injustice are interwoven into women's everyday lives through social structures and institutions (Daley, McCann, Mountz, \& Painter, 2017 in this journal; Mollett, 2017) and how women develop strategies to resist violence. I focus on feminist activists who organise against violence inflicted on women in their roles as women, activists, family members, colleagues and citizens in urban areas. The research is grounded in interviews, focus-group discussions and participant observation with feminist activists in Tegucigalpa and San Pedro Sula, Honduras between 2013 and 2016.

I first demonstrate how the women interviewed experience violence in their daily lives through emotions such as fear and unsafety. Participants felt that violence was normalised by militarisation and increased armed violence on the streets. Violence then was a constant feeling of having one's rights violated and experiencing that violation. 
Second, I argue that women's bodies become battlefields through structures and governmental institutions. Such structures and institutions include militarisation expressed through physical and verbal violence by military and police forces, institutional violence such as domestic violence, restrictions on women's reproductive rights, and impunity of violence against women. Third, I expose how these different forms of violence are both intimate and global and then draw connections to larger socio-political and economic power regimes such as foreign military aid to the Honduran government or multinational development projects.

In the final part of this paper, I briefly discuss collective self-care as a grassroots security practice, which the activists in this study developed as an alternative measure to state security. I present collective self-care as a feminist imaginary of security and link this practice with academic work on the feminist ethics of care. The study therefore responds to feminist geographers' call to view how informal and institutional networks perpetrate or resist forms of violence instead of focusing merely on state institutions. It seeks to understand processes that inform the expressions of violence instead of (or in addition to) seeking policy solutions (Springer \& Le Billon, 2016).

I conclude that violence against women in Honduras is not based on a single place and urge empirical research to focus on the body and promote solidarity, movement building and well-being rather than masculinist ideas of the protection of civilians and territory.

\section{Feminist geopolitics: An embodied view of violence}

Feminist geopolitics regards domestic, private and global spaces from an embodied view as part of a 'single complex of violence' (Pain, 2015). Women's everyday experiences or everyday violence referred to in this paper include more than physical harm; they are intimate and include invisible forms of violence such as deprivation, fear, humiliation, vulnerability and 'ugly feelings' such as anger (Pratt \& Rosner, 2012). An embodied view of violence then means looking at the ways that violence itself as well as its emotional and psychological effects are wound into everyday lives and even what it means to live (Sjoberg, 2014). Structural violence occurs without a single person touching another and may include political, social, economic and environmental factors (Moser \& McIlwaine, 2006) whereas institutional violence is caused, for example, by the police or military. Consequently, women's embodied experiences reveal how structural ${ }^{1}$ and institutional violence are forms of oppression that produce geopolitical and geo-economic violence (Brown \& Staeheli, 2003; Fluri \& Piedalue, 2017; Wright, 2004). In addition to gender, violence affects women differently due to their ethnicity, race, class and nation, among others (Hyndman \& Alwis, 2003).

Scholars have argued that violence against women is rooted in processes that are not only structural and institutional but also, in an increasingly globalised world, rooted in capitalism and militarism (True, 2012). These studies have shown, for example, that the international political economy can render women insecure through poverty, a gendered division of labour, and trafficking in women (Blanchard, 2003). Numerous actors in militarism are involved in complex global flows, including engineers, scientists, producers, sellers, intermediaries as well as buyers and users of arms, landmines, missiles, aircrafts and other resources (Enloe, 2016).

Discourses of globalisation have been criticised for describing women as powerless victims and global capitalism or militarism as overpowering systems (Pratt \& Rosner, 2012) but modern-day conflicts involve many scales, levels and actors, not only states or global economic or military powers (Fluri, 2009). Feminist geographers have therefore suggested an embodied view, which challenges binaries like global/local and public/private because the body crosses over spatially constructed boundaries (Pratt \& Rosner, 2006, 2012).

Feminist geopolitics has particularly studied violence in conflict as a spatially constructed phenomenon. In conflicts, people's bodies are seen as territory or property and they become public sites of violence on which constructions of the nation and its boundaries take place (Hyndman, 2004). These studies have demonstrated that violence in conflict moves across spaces and extends to violence in the home (Pain, 2015) and from war to peace time, including through militarism. Pain argues that militarism and domestic violence are part of the same complex system of violence:

Military strategy is also-intimate: domestic violence is also-political. In both cases, these dynamics are made and lived. Wound into everyday lives, they are perpetrated, negotiated and resisted by individuals and groups of people 
in specific ways. They intersect with and frequently feed off obligations and customs of care, emotion, and social relations with others. And they are framed through gender, race and class, and refracted through the histories of places, nations and citizenship' (Pain, 2015, p. 64).

Violence against women, including violence in conflicts and in partnerships, fuels the logic of 'masculinist protection' and the myth of a dominant male protecting a weaker female in which the female is unable to protect herself (Cuomo, 2013). This serves to create feminine and masculine identities but also to create an understanding of protection about who should be protected and by whom (Mohanty, 2013). Most importantly, such attitudes and practices neglect the everyday lives and self-identified needs of those who receive protection (Cuomo, 2013). Moreover, violence is normalised in contexts outside of conflicts. For example, Christian et al (2016) have shown how sexualised violence against women is often rendered banal when it happens outside of conflicts and as part of daily life.

Particularly state-security approaches overlook patriarchal power regimes as well as how such regimes have primarily held political and economic power and how conflicts have played out on (women's) bodies (Pain, 2015). Such global orders and patriarchal values together produce and reproduce conflict, inequality, violence as well as patriarchal attitudes and practices.

Feminist activists and scholars throughout the world have challenged the notion of security and extended its meaning to include the community and environment instead of merely individuals or the state. They have used the notion of care as a critical response to global neoliberal politics, which rely on profit and production (De la Bellacasa, 2012; Lawson, 2007; Robinson, 2013). My understanding of care is based on the definition by Tronto and Fisher, which includes 'everything that we do to maintain, continue and repair our world so that we can live in it as well as possible, including our bodies, ourselves, and our environment, all of which we seek to interweave in a complex, life-sustaining web' (Fisher \& Tronto, 1990, p. 40). Collective self-care, then, is based on the idea that security-building happens through ourselves and our bodies (Mountz et al., 2015; Robinson, 2013). I use this notion of care to analyse activists' strategies against everyday violence.

This paper draws on these studies and develops an embodied perspective on violence in order to understand how feminist activists in Honduras have experienced violence in their everyday lives through feelings, structures, institutions and their intimate and global implications and as a result, developed their own strategies of security based on care.

\section{Feminist perspectives: Reflections on methods \& methodology}

This study focuses on feminist activists in Tegucigalpa and San Pedro Sula, Honduras, and therefore, relies on lived experiences of a specific group of activists with different intersectional identities who all identified themselves as feminists. Given this focus, it seeks not to homogenise women but rather to analyse how these feminist activists perceived and experienced violence (McCall, 2005). Hence, feminist perspectives here refer to both the activists interviewed as well as the study's theoretical and methodological background. Following feminist political geographic scholarship, feminist perspectives mean practices that 'pay explicit attention to women, gender and sexuality, and the ways in which other axes of identity are entwined with these in the relationships of power, oppression and domination that organise and construct the social world (Brown \& Staeheli, 2003, p. 247)'. In my research, I concentrated particularly on four methodological reflections. First, in line with feminist scholars, I reflected on how using women's narratives instead of quantitative data on violence gives agency to women (Daley \& Popplewell, 2016). Women's narratives can better reveal the complexities and structural causes of violence than a view of violence as a static concept. Hence, this paper is based on interviews, focus-group discussions and participant observation. The basis for my research began in 2008 and 2009, when I worked at the feminist organisation Centro de Estudios de la Mujer - Honduras in Tegucigalpa. Between January and December 2013, I conducted 20 semi-structured interviews and 3 focus-group discussions with over 30 activists and government representatives as well as participant observation at workshops and events on women's rights in San Pedro Sula and Tegucigalpa in Honduras. In addition, my research makes use of meetings and discussions between 2014 and 2016 with over 20 Honduran women activists at the UN in Geneva, Switzerland. I focus on activists' statements from three feminist organisations in Tegucigalpa and San Pedro Sula: Centro de Estudios de la Mujer-Honduras 
(CEM-H) in Tegucigalpa, Foro de Mujeres por la Vida in San Pedro Sula, and Centro de Derechos de las Mujeres (CDM), based in both cities. All three organisations focus their activities on feminist issues such as promoting women's reproductive rights and political participation as well as organising around violence against women. In addition, the three organisations are members of collective networks, such as the Red Nacional de Defensoras de los Derechos Humanos en Honduras.

My second reflection centred around my aim to pose research questions that were important for the participants involved in the study. In both interviews and informal conversations, I asked interviewees about challenges to women's rights in Honduras. Feminist activists spoke about everyday experiences with violence, criticised the government's militarist security measures and expressed the importance of self-care as a strategy against violence. The interview analysis using MAXQDA software revealed three main topics, which I will discuss in my findings: Feelings of fear and unsafety, structural and institutional violence, and the global and intimate implications of violence.

Third, following feminist research, I reflected on women having different experiences of violence based on ethnicity, race, sexuality, class and location (Collins, 2000; Crenshaw, 1991). This research has shown that women in poor communities are the most marginalised and face multiple forms of societal violence. In addition, there is important work, for example, on Honduran women of indigenous and Afro-American descent in rural communities who are particularly at high risk of experiencing discrimination and violence (Brondo, 2013; Mollett, 2016). Keeping these differences in mind, a feminist perspective seeks to highlight the specificity of women in the face of exclusion, discrimination and inequality (IM Defensoras, 2015).

Fourth, as Katz (1992) has argued, I considered that field sites are part of larger global political-economic processes, instead of 'out there,' even though researchers often contextualise activists and their challenges in their local context and neglect these larger processes. Appropriately, feminist methodology stresses the responsibility of the researcher to think beyond the field and to address forms of global injustice (Katz, 2012; Okazawa-Rey, 2009). A feminist perspective stresses the importance of also seeing patriarchal structures in the international community and to acknowledge that everything is androcentric, including the theory of comprehensive protection of human rights with its instruments and mechanisms (IM Defensoras, 2015).

\section{Protection: For whom, by whom and from what?}

In recent years, international organisations have designated Honduras one of the most violent countries in the world (OHCHR, 2016; UNODC, 2013). According to reports, violence results from multiple factors including organised crime, corruption, a high level of socio-economic inequality and militarisation. In addition, these reports have shown that violence by military and police forces has increased since the coup d'état in 2009.

On 28 June 2009, there was a coup d'état in Honduras in which the political allies of the Liberal Party and the National Party together with the military ousted the governing president Manuel Zelaya. The coup sparked large resistance movements and mobilised women across different groups and social identities under the collective resistance movement Feministas en Resistencia. They protested on the streets against the ousting of the president but also against human rights violations by the military and police forces (Frank, 2013; Jokela-Pansini, 2016; Mendoza, 2010; Ronderos, 2011). Honduran civil society's Truth Commission reported over 5,000 human rights violations during the protests (Comisión de Verdad, 2013).

Similar to other countries in Latin America, Honduras was governed by a military regime for several decades during the $20^{\text {th }}$ century. In the $1980 \mathrm{~s}$, the military committed serious human rights violations and was involved in torture and the 'disappearances' of those who opposed the government. Civil-society groups, including some feminist organisations, organised to reduce the military's powers, especially in internal-security investigations (Call, 2002). During the decades following the democratisation process in the 1990s, Honduras went through a process of demilitarisation and the Honduran constitution prohibited military involvement in policing duties.

However, in more recent years since the coup in 2009, the Honduran government has bolstered military and police forces to fight violence and enhance citizen security (UNODC, 2013), thus normalising the presence of military in public spaces. The government increased its military spending from $4.8 \%$ in 2012 to $6.9 \%$ in 2015 (SIPRI, 2017). Additionally, in January 2013, the country's legislature revised the constitution and permitted a military police force. Consequently, the government launched the 'military police of public order' (La Policia Militar del Orden 
Público PMOP), which consists of 4,000 members. The military police focus particularly on urban areas and in 2017, the government increased its troops in Tegucigalpa and San Pedro Sula by 500 soldiers in each city.

According to government statements, ${ }^{2}$ the PMOP defends citizen security by acting against organised crime and common delinquencies to maintain public order and 'bring back peace and citizen security' to Honduras. As the UN Special Rapporteur on Human Rights has noted, the introduction of the military police was understandable as an emergency response given the political circumstances in Honduras after the coup (OHCHR, 2016). However, according to the Special Rapporteur, the soldiers' mandate is to prevent abuses but they are trained for the conduct of war and not for providing citizen security.

Scholars have found similar security strategies of a state's dealing with violence through armed forces in other countries. O'Neill and Thomas (2011) argue that in Guatemala, for example, the state has framed the structural causes of violence as individual violence carried out by 'violent actors', such as gangs or delinquents. Organised crime and gangs largely contribute to violence particularly in urban areas (Moser, 2004; Wilding, 2016). However, governments often use these kinds of alleged threats to legitimise violent interventions to protect common societal values and interests and to create and sustain the fear of a threat (Cohen, 2011). Such a strategy can also be seen in the ways that governments throughout the world fortify their national security against internal and external threats, such as terrorism (Sjoberg \& Gentry, 2015). Further, such a security strategy can enable governments to use security measures on its opponents that would normally not be tolerated, such as the use of extreme violence. A recent example of these kinds of security measures is, for instance, the arrests and assassinations of protesters by the Honduran police and military after the national elections in November 2017. Between 30 November 2017 and 21 January 2018, the Honduran police and military forces killed 31 protesters, wounded hundreds and arrested over a thousand in the name of national security. Enloe (2016) argues that in militarised societies, 'threats appear magnified, enemies seem to multiply, secrecy is more easily justified, intrusions of the state into civilians' lives are easier to rationalise, and compromises to civil rights can become legitimised'. In such societies, this militarisation normalises violence, especially in a country struggling with corruption and a weak democratic system.

In addition, such security strategies neglect the questions of who is protected and how militarisation boosts violence, particularly on women. Violence against women in Honduras has increased in the past several years, including femicide, domestic violence, sexual harassment and labour-rights violations (OHCHR, 2016). Between 2010 and 2014, femicides rose by $250 \%$ and 2,592 women were killed because of their gender (IACHR, 2017). Latin American feminists have called femicide a hate crime against women because of the brutal ways the victims are murdered. Women's mutilated corpses, left in public places, are used as a weapon to spread terror amongst women (Kennedy 2006 in Prieto-Carrón, Thomson, \& Macdonald, 2007). In Honduras, allegations of missing female children, teenagers and women increased by $306 \%$ between 2008 and 2015 . These disappearances of women also involve other types of violence against women. In some cases, disappearances are related to transnational crimes such as human trafficking and smuggling (CEDAW Platform Honduras, 2016). Moreover, women in poor and marginalised communities endure multiple forms of violence because they are usually invisible to any form of state intervention (Ronderos, 2011).

International organisations have reported that violence and impunity for attacks on human rights activists escalated after the coup d'état in 2009, particularly against environmental activists (OHCHR, 2016). The government's declaration 'Honduras is open for business' has attracted foreign companies to invest in so-called development projects, which are located particularly on indigenous people's lands and the coastal region of the Garifuna people (Brondo, 2013). This has resulted in land grabbing and the persecution and killing of indigenous and afroindigenous people defending their lands. These recent developments concerning violence on women and on (women) human rights activists raise the questions as to who is protected by armed security measures and how the safety of those who oppose state-based violence is guaranteed.

\section{Violence as a feeling of fear and unsafety}

What we [women] are dealing with on a daily basis is state violence and violence caused by other criminal sectors, which is everywhere, so we are in constant resistance against different aggressors. Previously, women in their 
communities fought against poverty, lack of water, or epidemic diseases. Now [we fight] against gangs, assassins, against corrupt police, enemies that are a lot harder [to fight] because they stand in front of you with guns.

The statement was part of a conversation with a feminist activist who described everyday challenges of women in her home town San Pedro Sula. Violence by the state and violence by 'other criminal sectors' such as gangs resulted in feelings of fear and unsafety. Sweet and Ortiz Escalante (2015, p. 1832) call such perceptions of unsafety 'a mirror of gendered power relations in society', which limits women's mobility and use of space. Such fear in everyday lives resulted in violence being 'everywhere': societal violence had existed before but gangs and corrupt police officials reinforced everyday violence particularly because they were armed. The participants explained that because violence was everywhere, everyone became a potential perpetrator, which increased their feeling unsafe in public spaces. Going to work, picking up children from school or going to demonstrations, the participants felt alert to being harassed, attacked, robbed or even killed.

These statements demonstrate how violence affects women emotionally and 'what it means to live' (Sjoberg \& Gentry, 2015); it begins with the feeling in one's body of having one's rights violated. In such cases, women's perceptions of unsafety were a product of systemic and structural violence rather than actual attacks (Sweet \& Ortiz Escalante, 2015).

Because so much violence happens and I think we are tired and angry. When I pass the newspaper stand I feel angry because they write, 'He killed her because she went out, he took her and killed her because she was dressed up that way', or 'he was jealous so he killed her'. So, all of this is making us ill and we need to find ways to feel better and continue our struggle. And to be strong so that these things won't affect us.

The focus-group participant quoted above described how violence in her view was always present. She and other activists shared their experiences on sexual harassment and how public discourses blamed violence on the victims. Experiencing violence and reading about violence against women made these women feel physically ill and evoked feelings in them of anger and fatigue. Hence, the women interviewed felt violence also through other women's experiences. Violence according to these public discourses was a normal outcome because the victim failed to take care of her own security. This shows how violence against women, such as sexual violence, is rendered banal in everyday contexts (Christian et al., 2016). In this context, it means that women are expected to accept the violence happening to them and other women in society, to seek to avoid violence by dressing appropriately, and to take responsibility if they are attacked.

The government thinks that with the police and military police on the streets we are going to resolve problems of violence and insecurity, while there are in reality structural problems that sustain this situation. There are high levels of corruption [...] and in this [situation] we, as women, are most affected because imagine, we are speaking of 483 femicides up to October [2013], only based on what is reported in the news. And of these, only 1\% end in conviction.

This activist emphasised that armed violence, whether by organised crime or military forces, intensifies violence against women.

Similar to this activist's statement, the shadow report of the Honduran feminist organisations on CEDAW in 2016 stated that the militarisation strategies of the Honduran government were one of the key challenges concerning violence against women (CEDAW Platform Honduras, 2016). The organisations urged the state to limit military presence in public institutions and spaces where the armed forces were unnecessary. In addition to experiencing physical violence by military officials, women felt unsafe in the presence of military.

These statements demonstrate how violence and its effects are embedded into women's everyday lives through emotions such as feelings of fear and unsafety. These were linked to militarisation, increased gang violence, and the normalisation of sexualised violence against women on the streets. Violence thus was a constant feeling of having one's rights violated and experiencing that violation. 


\section{Women's bodies as battlefields: Structural and institutional violence}

We are against a system which has repressed us even more after the coup d'état and which makes it look like all the violence we are experiencing is normal, and people see it this way. But we are demonstrating that it can't be normal. We don't accept that they penalise abortion or prohibit the morning after pill; we risk our lives because we are against [the government]. And not only with the system but also with the people who have grown up in this system. Because they think that we are rebels, although what we want is right. What we want is true peace, which is a huge challenge.

Activists interviewed repeatedly emphasised violence caused by structures and institutions, including the military. Many interviewees drew connections with the coup in 2009 and its aftermath because the conflict had increased the number of armed forces in public spaces. Activists claimed it was difficult to perceive military officials as protectors because they represented a system that contributed to violence. The women interviewed explained how, during demonstrations against the coup in 2009, military officials had harassed activists physically and verbally. Some had shouted at women to go home to their families, called them whores or threatened them with sexual violence (Menjívar \& Walsh, 2017; Ronderos, 2011). Such verbal and physical violence had continued at demonstrations the activists had attended even in the years following the coup.

Scholars have found that in Honduras, the legal and judicial system's actions and inactions have contributed to violence on women (Menjívar \& Walsh, 2017). In addition to physical and verbal violence, activists interviewed reported that the post-coup regime had begun restricting women's reproductive rights, for example by prohibiting emergency contraception. Such institutional violence by military officials and institutions confirms scholars' hypotheses that gendered violence and other inequalities persist from conflict to post-conflict situations (Pain, 2015). However, as the participant's statement above shows, activists perceived it to be difficult to challenge restrictions on women's rights because state institutions and individuals framed feminists as rebels.

Another activist reflected on how conflict and organised crime affected violence at home:

So when we look at different forms of violence, at intimate and non-intimate femicides, we see a high percentage of femicides related to partners, ex-partners, boyfriends, and connections? their partners have with organised crime. So in the end, in this context, women and their bodies become battlefields.

The activist's statement on femicide corroborates notions of feminist geopolitics on how intimate violence is not separate from violence in conflict (Pain, 2015). Women's bodies become battlefields of conflict because the justice system fails to protect victims of domestic and sexual violence. In this way, institutional practices normalise violence, and society no longer expects law enforcement officials to respond to complaints of violence against women. For example, in general, the police handle domestic and sexual violence cases with systematic indifference. ${ }^{3}$ This situation is reported in The Honduran Universal Periodic Review (UPR) statement by civil society organisations on violence against women (The Advocates for Human Rights et al 2014). It also states that women rarely report rape cases because the law enforcement and criminal justice systems hardly respond to these. According to the report, the law criminalises domestic violence but sanctions the first and second offenses of domestic violence merely by community service and 24-hour preventive detention if the violator is 'caught in the act.' Hence, laws on violence against women are only as effective as their implementation (Wilding, 2016). The statements analysed here show how women's bodies become battlefields through the normalisation of violence by structures and state institutions. These include militarisation, institutional restrictions on women's rights, and the impunity of violence against women at home.

\section{Intimate and global implications of violence}

This whole situation of war that is taking place in this region is justified by drug trafficking. This has brought an enormous increase in violence in Honduras: Ninety-two murders per 100,000, almost one per thousand inhabitants, 
which is more than in a situation of war. And this has to do with this war. The systematic corruption in the police, the involvement of maras (gangs), the police and state officials in this 'war on drugs' and in drug dealing. So, in other words, it is a hard situation.

This statement demonstrates how violence against women is not only place-based but most importantly, rooted in the structures and processes of political economy that are increasingly globalised (True, 2012). The activist here refers to Honduras' ranking as the most dangerous country in the world in 2013 with 92 murders per 100,000 but highlights that the war on drugs is systematic and multi-scalar and includes the international community. For example, the US government increased its military presence after the coup and sought closer US military involvement on the ground for combatting the drug trade in Central America (Cockburn, 2013). Numerous scholars and politicians have argued that countries supporting militarisation are contributing to violence in Honduras and should suspend their military aid to the government (Frank, 2013).

In this context, in 2013, over 145 civil-society organisations including feminist organisations from Honduras called on the then US president Obama and other presidents in the Americas to change policies that promote militarisation to combat organised crime. The organisations stated in a letter ${ }^{4}$ that militarisation had led to 'a dramatic surge in violent crime, often reportedly perpetrated by security forces themselves.' The letter continued that human rights abuses against families and communities were, in many cases, directly attributable to failed and counterproductive security policies that had militarised their societies in the name of the 'war on drugs' (see also Beeton \& Watts, 2016).

In addition to the 'war on drugs,' participants interviewed for this study were concerned about the persecution of (women) leaders in Honduras and worldwide. According to international organisations, more than a thousand human rights defenders globally were killed, harassed, detained or subjected to other violations. An international investigatory group of lawyers (International Advisory Group of Experts - GAIPE) and the local police confirmed that in March 2016, a group including private-company employees, government officials and security forces murdered Berta Cáceres, an indigenous, environmental and women's rights defender, because she had organised against a hydroelectric project in Agua Zarca, Honduras. The project was funded by local actors, but also by the Finnish Finnfund and the Dutch Development Bank FMO, supported partly as development projects by the respective governments (Global Witness, 2015).

According to human rights organisations, the first police statements to characterise Cáceres' killing as a romantically or sexually motivated 'crime of passion' - as well as the sexualised threats she received before her murder - are exemplary of the gendered misrepresentation of women's human rights activism ${ }^{5}$. Cáceres' death triggered a global solidarity movement, which pressured the Honduran government to convict the men responsible for her murder. The Court sentenced seven men who had been hired by executives within Desa, the local hydroelectric company operating on the Lenca community's lands (Front Line Defenders, 2018). Cáceres' murder, police statements and the international solidarity movement against her murder show how the body crosses over spatially constructed boundaries such as the local and the global (Pratt \& Rosner, 2006). Consequently, women's bodies become public sites of violence in the name of national and global security and development (Hyndman, 2004).

\section{Collective (self-)care: Embodied strategies of resisting everyday violence}

\section{[...]So, all of this is making us ill and we need to find ways to feel better and continue our struggle. And to be strong so that these things won't affect us.}

Women and feminist activists worldwide have drawn on self-care practices to deal with the previously described experiences of everyday and embodied violence and 'to find ways to feel better.' The women human rights defenders' network in Honduras and in the Mesoamerican region, including the organisations interviewed for this study, understand violence as both psychological (e.g. threat, fear, feeling of insecurity and trauma) and physical (e.g. harassment and sexual violence) (IM Defensoras, 2013). Self-care in the network's understanding is based on the idea of building a community and thus recognising each other as part of a collective ${ }^{6}$. The notion of self-care, 
autocuidado, in the Latin American context (and beyond) is entangled with indigenous worldviews of buen vivir, living well (Gudynas, 2011) and feminist ideas. In this regard, notions such as security or development refer not only to individuals and the collective but rather, to a broader community and the environment. Activists and scholars have described both buen vivir and self-care as critical responses to global neoliberal politics, which rely on profit and production (Escobar, 2014; Mountz et al., 2015; Robinson, 2013). Hence, this understanding together with the activist's statement reflects the definition of care by Tronto and Fischer, which includes our bodies, ourselves, and our environment (Fisher \& Tronto, 1990).

Feminist scholars have argued that care is central for feminist thinking. It is based on mutuality and trust, the idea of thinking-with-many, of thinking and doing collectively (Lawson, 2007; Puíg de la Bellacasa, 2017). For example, in a workshop I attended during my fieldwork, such practices included discussing problems related to activism, sharing best practices and using relaxation and self-expression exercises. Talking about lived experiences in numerous roles - as feminists, women human rights defenders, survivors of domestic violence, migrants and inhabitants of neighbourhoods in which maras (gangs) have a strong presence - was crucial for individual and collective wellbeing. As one activist explained, sharing personal stories and listening to others with care was a crucial part of 'feeling safe' and of building security.

I agree with the aforementioned feminist scholars who argue that if we want to care for others, we need to build social institutions that encourage care and emphasise mutuality and wellbeing. These studies reflect activists' needs described in the statement above, which focus on finding ways to 'feel better' and to 'be strong' in order to cope with the challenges of violence and (in)security. In further conversations, activists emphasised the need of such collective spaces because they also defended the rights of others, not only themselves.

Besides contributing to personal and collective wellbeing, intimate and social cooperation coupled with caring for others may also provide the ground for new or alternative political opportunities (Pratt \& Rosner, 2012). Hence, a feminist vision of care is political and thinking about care from marginalised experiences has a potential to transform knowledge (Fisher \& Tronto, 1990; Lawson, 2007; Robinson, 2008). Such practices strengthen solidarity building, which the activists interviewed considered crucial for responding to challenges against women's rights. By reimagining care as not just relational but also as a political practice and a resource, we draw attention to how both care as responsibility and care as emotion are constituted globally and thus, beyond place.

\section{Conclusions}

This study explored how feminist activists in Honduras experienced and perceived the violence that shaped their everyday lives. The research was based on interviews, focus-group discussions and participant observation with feminist activists in Tegucigalpa and San Pedro Sula, Honduras between 2013 and 2016 explained how embodied approaches help to understand violence against women as a complex system.

The study introduced three concepts of violence: firstly, this article demonstrated that violence and its effects are embedded into women's everyday lives through feelings of fear and unsafety. Participants linked their sense of violence being everywhere to the normalisation of sexualised violence against women on the streets, increased gang violence and militarisation. Violence thus became a constant feeling of having one's rights violated and experiencing that violation.

Secondly, the study depicts how women's bodies become battlefields through structures and institutions such as militarisation, restriction of women's reproductive rights and domestic violence, all of which are parts of the same complex. This corroborates notions in feminist geography claiming that when violence is embedded in and produced by socio-political oppression, it is also intimate (Pain, 2015).

Thirdly, the article considers violence against women as both intimate and global and then shows how different forms of violence - emotional, structural and physical - are entangled with global political and socio-economic processes. It shows through the two examples of foreign military aid and a hydroelectric project in Agua Zarca how women's bodies become public sites of violence in the name of national and global security and development (Hyndman, 2004).

The paper contributes to feminist geographers' work seeking to denaturalise violence. It complicates the notion of violence and demonstrates that violence and its effects are embedded into women's everyday lives through different spatialities, scales and power regimes. Feminist scholarship emphasises the entanglements of global processes such 
as political economies and militarism with women's intimate, embodied, everyday experiences with violence. In line with this, I suggest that violence against women in Honduras is not based in a single place. Therefore, responses to violence against women should go beyond identifying women as 'victims' of individual violence and training military and police forces to protect them. It raises the questions of who gets to live a life free of violence and how. Finally, the paper shows how feminist activists adopted collective self-care practices as a strategy of resisting the threatening experiences of violence that envelop their everyday spaces because government institutions fail to provide protection or even side with the perpetrators. I argue, following feminist geographers (Lawson, 2007; Mountz \& Hyndman, 2006; Robinson, 2008), that such a strategy, besides enhancing individual and collective wellbeing, is a different way of doing politics and of building alternative imaginaries of security.

As Pratt and Rosner (2012) argue, "Feminist solidarity emerges not through some abstract identification as a woman or a feminist but through actual, unpredictable, sometimes angry or distrustful intimate relations, through the hard work of communication and collaboration." Hence, the paper suggests adopting feminist visions of care in empirical research and collective responses around violence and (in)security based on solidarity, movement building and wellbeing.

\section{Acknowledgements}

I would like to thank Doris Wastl-Walter, Elham Manea and Elisabeth Militz for their valuable comments on earlier versions of this paper. I am especially grateful to all the activists who shared their experiences and insights with me. Thank you also to the two anonymous reviewers for their insightful suggestions that helped improve the manuscript.

\section{Notes}

${ }^{1}$ I acknowledge that the terms structural and institutional violence are broad and cannot be separated from other forms of violence such as individual violence. See e.g. McIlwaine (1999) for an overview of different categorisations of violence.

${ }^{2}$ Documentos/BDL/2016/10608 (accessed 18 December 2017).

${ }^{3}$ See e.g. the report of The Advocates for Human Rights, the International Action Network on Small Arms and Comité de América Latina y el Caribe para la Defensa de los Derechos de las Mujeres-Honduras (2014) Universal Periodic Review 22nd Session - Honduras. Violence against Women. Available at https://www.uprinfo.org/sites/default/files/document/honduras/session_22_-_mai_2015/js14_upr22_hnd_e_main.pdf (accessed 11 November 2017).

${ }^{4}$ See https://justassociates.org/sites/justassociates.org/files/eng_letter_to_heads_of_states_-_sica_april_30_2013.pdf and https://nacla.org/article/us-re-militarization-central-america-and-mexico.

${ }^{5}$ See also ISHR (2016) Open Statement to the Human Rights Council, the Special Rapporteur on Violence against Women, and the Working Group on Discrimination against Women in Law and Practice. International Service for Human Rights. Available at http://www.ishr.ch/news/agenda-2030-women-defenders-call-inclusion-accountability-and-justice\#Statement on WHRDs (accessed on 28 October 2017).

${ }^{6}$ In addition to self-care responses focusing on wellbeing, feminist organisations had been taking precautionary (human) security measures against violence. Such measures included setting up video cameras and providing safety instructions for employees and visitors. For example, after an interview at a feminist organisation, the interviewee instructed me that the organisation's protocol was to wait inside for transportation. In addition, there were video cameras in front of the office because of previous assaults against the employees. In November 2013, I attended a workshop of a feminist election observation group preparing its work for the upcoming national elections. The workshop organisers instructed the activists to stay in groups to avoid assault or harassment on the streets. These strategies are important to mention here because they indicate how activists think collectively about security. However, I regard these strategies in this context as security practices against immediate threats of violence rather than as self-care practices focusing on feeling better. 


\section{Bibliography}

Beeton, D., \& Watts, R. (2016). No, Honduras Isn't Necessarily Getting Safer. Despite cheerleading from some, U.S. security aid to Honduras continues to sow violence. NACLA Report on the Americas, 48(4), 315-318.

Bichsel, C. (2017). Violence as a human condition: Recent contributions from the German social sciences. Environment and Planning D: Society and Space, 35(3), 550-560.

Blanchard, E. M. (2003). Gender, International Relations, and the Development of Feminist Security Theory. Signs: Journal of Women in Culture and Society, 28(4), 1289-1312.

Blomley, N. (2003). Law, property, and the geography of violence: The frontier, the survey, and the grid. Annals of the Association of American Geographers, 93(1), 121-141.

Brondo, K. V. (2013). Land Grab: Green Neoliberalism, Gender, and Garifuna Resistance in Honduras. Tucson: University of Arizona Press.

Brown, M., \& Staeheli, L. (2003). “Are we there yet?” feminist political geographies. Gender, Place \& Culture, $10(3), 247-255$.

Call, C. T. (2002). War Transitions and the New Civilian Security in Latin America. Comparative Politics, 35(1), $1-20$.

CEDAW Platform Honduras. (2016). Assessing the Government's Progress in Implementing the United Nations Convention on the Elimination of all Forms of Discrimination Against Women 2007-2012. Retrieved from http://tbinternet.ohchr.org/Treaties/CEDAW/Shared Documents/HND/INT_CEDAW_NGO_HND_25392_E.pdf

Christian, J., Dowler, L., \& Cuomo, D. (2016). Fear, feminist geopolitics and the hot and banal. Political Geography, 54, 64-72.

Cockburn, C. (2013). War and security, women and gender: an overview of the issues. Gender \& Development, $21(3), 433-452$.

Cohen, S. (2011). Whose side were we on? The undeclared politics of moral panic theory. Crime, Media, Culture, 7(3), 237-243. 
Collins, P. H. (2000). Black feminist thought: knowledge, consciousness, and the politics of empowerment. New York: Routledge.

Comisión de Verdad. (2013). La voz más autorizada es la de las víctimas. Informe Final 2013. Tegucigalpa. Retrieved from http://iepala.es/IMG/pdf/Informe_Comision_de_Verdad.pdf

Crenshaw, K. (1991). Mapping the Margins: Intersectionality, Identity Politics, and Violence Against Women of Color. Stanford Law Review, 43(6), 1241-1299.

Cuomo, D. (2013). Security and Fear: The Geopolitics of Intimate Partner Violence Policing. Geopolitics, 18(4), 856-874.

Daley, P., McCann, E., Mountz, A., \& Painter, J. (2017). Re-imagining politics \& space: Why here, why now? Environment and Planning C: Government and Policy, 35(1), 3-5.

Daley, P., \& Popplewell, R. (2016). The appeal of third termism and militarism in Burundi. Review of African Political Economy, 43(150), 648-657.

De la Bellacasa, M. P. (2012). Nothing Comes Without Its World: Thinking with Care. The Sociological Review, 60(2), 197-216.

Dowler, L., \& Sharp, J. (2014). A feminist geopolitics? In J. Dittmer \& J. Sharp (Eds.), Geopolitics: An Introductory Reader. London: Routledge.

Enloe, C. (2016). Globalization and militarism. Feminists make the link(2nd ed.). London: Rowman \& Littlefield.

Escobar, A. (2014). Development, critiques of. In G. D'Alisa, F. Demaria, \& G. Kallis (Eds.), Degrowth. A vocabulary for a new era (pp. 57-60). New York: Routledge.

Fisher, B., \& Tronto, J. C. (1990). Toward a feminist theory of care. In E. K. Abel \& M. K. Nelson (Eds.), Circles of care: work and identity in women's lives. New York: State University of New York Press.

Fluri, J. L. (2009). Geopolitics of Gender and Violence “from Below.” Political Geography, 28(4), 259-265.

Fluri, J. L., \& Piedalue, A. (2017). Embodying violence: critical geographies of gender, race, and culture. Gender, Place \& Culture, 24(4), 534-544. https://doi.org/10.1080/0966369X.2017.1329185 
Foucault, M. (1978). Discipline and Punish: The Birth of the Prison. Contemporary Sociology, 7(5), 1-333. https://doi.org/10.2307/2065008

Frank, D. (2013, November 22). Hopeless in Honduras. Foreign Affairs. Retrieved from https://www.foreignaffairs.com/articles/honduras/2013-11-22/hopeless-honduras

Front Line Defenders. (2018). Case history: Berta Cáceres. Retrieved September 20, 2019, from https://www.frontlinedefenders.org/en/case/honduras-berta-caceres-killed

Global Witness. (2015). How many more? 2014's deadly environment: the killing and intimidation of environmental and land activists, with a spotlight on Honduras. London: Global Witness Limited.

Gudynas, E. (2011). Buen Vivir: Today’s tomorrow. Development, 54(4), 441-447.

Hyndman, J. (2004). Mind the Gap: Bridging Feminist and Political Geography through Geopolitics. Political Geography, 23(3), 307-322.

Hyndman, J., \& Alwis, M. De. (2003). Beyond gender: Towards a feminist analysis of humanitarianism and development in Sri Lanka. Women's Studies Quarterly, 31(3/4), 212-226.

IACHR. (2017). IACHR Annual Report 2017. Retrieved from http://www.oas.org/en/iachr/docs/annual/2016/TOC.asp

IM Defensoras. (2013). Policy and practice note. A Feminist alternative for the protection, self-care, and safety of Women Human Rights Defenders in Mesoamerica. Journal of Human Rights Practice, 5(3), 446-459.

IM Defensoras. (2015). Violence against Women Human Rights Defenders in Mesoamerica 2012-2014 Report. Retrieved from http://im-defensoras.org/wp-content/uploads/2016/04/286224690-Violence-AgainstWHRDs-in-Mesoamerica-2012-2014-Report.pdf

Jokela-Pansini, M. (2016). Spatial Imaginaries and Collective Identity in Women's Human Rights Struggles in Honduras. Gender, Place and Culture, 23(10), 1465-1479.

Katz, C. (1992). All the World is Staged: Intellectuals and the Projects of Ethnography. Environment and Planning D: Society and Space, 10(5), 495-510.

Katz, C. (2012). Partners in Crime? Neoliberalism and the Production of New Political Subjectivities. In N. 
Laurie \& L. Bondi (Eds.), Working the Spaces of Neoliberalism: Activism, Professionalisation and Incorporation (pp. 227-235). Oxford: Blackwell.

Koopman, S. (2011). Alter-geopolitics: Other securities are happening. Geoforum, 42(3), 274-284.

Lawson, V. A. (2007). Geographies of care and responsibility. Annals of the Association of American Geographers, 97(1), 1-11.

McCall, L. (2005). The Complexity of Intersectionality. Signs: Journal of Women in Culture and Society, 30(3), 1771-1800.

McIlwaine, C. (1999). Geography and development: Violence and crime as development issues. Progress in Human Geography, 23(3), 453-463.

Mendoza, B. (2010). Reflexiones teoricas para un movimiento feminista de la no-violencia. Tegucigalpa: Centro de Estudios de la Mujer Honduras (CEM-H).

Menjívar, C., \& Walsh, S. D. (2017). The architecture of feminicide: The state, inequalities, and everyday gender violence in Honduras. Latin American Research Review, 52(2), 221-240.

Menjívar, C., \& Walsh, S. D. (2018). Gender violence: one driver of the Central American caravan. Retrieved from https://genderpolicyreport.umn.edu/gender-violence-one-driver-of-the-central-americancaravan/?fbclid=IwAR2XIQWLg3bf8q2nOD3IfHrpde2CWmB0--jYh8jVrnian6OyI1HTnhU3Dls

Mohanty, C. T. (2013). Transnational Feminist Crossings: On Neoliberalism and Radical Critique. Signs: Journal of Women in Culture and Society, 38(4), 967-991.

Mollett, S. (2016). The Power to Plunder: Rethinking Land Grabbing in Latin America. Antipode, 48(2), $412-$ 432.

Mollett, S. (2017). Irreconcilable differences? A postcolonial intersectional reading of gender, development and Human Rights in Latin America. Gender, Place \& Culture, 24(1), 1-17.

Moser, C. O. N. (2004). Urban Violence and Insecurity: An Introductory Roadmap. Environment and Urbanization, 16(2), 3-16.

Moser, C. O. N., \& Mcllwaine, C. (2006). Latin American urban violence as a development concern: Towards a 
framework for violence reduction. World Development, 34(1), 89-112.

Mountz, A., Bonds, A., Mansfield, B., Loyd, J., Hyndman, J., Walton-Roberts, M., ... Curran, W. (2015). For Slow Scholarship: A Feminist Politics of Resistance through Collective Action in the Neoliberal University. ACME: An International Journal for Critical Geographies, 14(4), 1235-1259.

Mountz, A., \& Hyndman, J. (2006). Feminist Approaches to the Global Intimate. Women's Studies Quarterly, $34(1 / 2), 446-463$.

O’Neill, K. L., \& Thomas, K. (2011). Securing the City. Neoliberalism, Space, and Insecurity in Postwar Guatemala. Durham: Duke University Press.

OHCHR. (2016). Preliminary Observations on the official visit to Honduras by the Special Rapporteur on Extrajudicial, Summary or Arbitrary Executions, 23 to 27 May 2016. Retrieved from http://www.ohchr.org/EN/NewsEvents/Pages/DisplayNews.aspx?NewsID=20030\&LangID=E

Okazawa-Rey, M. (2009). Solidarity with Palestinian Women: Notes from a Japanese Black U.S. Feminist. In J. Sudbury \& M. Okazawa-Rey (Eds.), Activist Scholarship. Antiracism, Feminism, and Social Change (pp. 205-223). Boulder: Paradigm Publishers.

Pain, R. (2009). Globalized fear? Towards an emotional geopolitics. Progress in Human Geography, 33(4), 466486.

Pain, R. (2015). Intimate War. Political Geography, 44, 64-73.

Pratt, G., \& Rosner, V. (2006). Introduction: The Global and the Intimate. Women's Studies Quarterly, 34(1/2), $13-24$.

Pratt, G., \& Rosner, V. (2012). The global and the intimate. Feminism in our time. New York: Columbia University Press.

Prieto-Carrón, M., Thomson, M., \& Macdonald, M. (2007). No More Killings! Women Respond to Femicides in Central America. Gender \& Development, 15(1), 25-40.

Puíg de la Bellacasa, M. (2017). Matters of care: speculative ethics in more than human worlds. Minneapolis: University of Minnesota Press. 
Robinson, F. (2008). The Importance of Care in the Theory and Practice of Human Security. Journal of International Political Theory, 4(2), 167-188.

Robinson, F. (2013). Global Care Ethics: Beyond Distribution, Beyond Justice. Journal of Global Ethics, 9(2), $131-143$.

Ronderos, K. (2011). Poverty Reduction, Political Violence and Women's Rights in Honduras. Community Development Journal, 46(3), 315-326.

SIPRI. (2017). SIPRI Yearbook 2017. Armaments, disarmament and international security. New York.

Sjoberg, L. (2014). Intimacy, Warfare, and Gender Hierarchy. Political Geography, 44, 74-76.

Sjoberg, L., \& Gentry, C. E. (2015). Introduction: Gender and Everyday/Intimate Terrorism. Critical Studies on Terrorism, 8(3), 358-361.

Slack, J., Martínez, D. E., Lee, A. E., \& Whiteford, S. (2016). The geography of border militarisation: violence, death and health in Mexico and the United States. Journal of Latin American Geography, 15(1), 7-32.

Springer, S., \& Le Billon, P. (2016). Violence and space: An introduction to the geographies of violence. Political Geography, 52, 1-3.

Sundberg, J. (2014). Decolonizing Posthumanist Geographies. Cultural Geographies, 21(1), 33-47.

Sweet, E. L., \& Ortiz Escalante, S. (2015). Bringing bodies into planning: Visceral methods, fear and gender violence. Urban Studies, 52(10), 1826-1845.

True, J. (2012). The political economy of violence against women. Oxford: Oxford University Press.

Tyner, J. (2016). Herding elephants: Geographic perspectives on gendered violence. Dialogues in Human Geography, 6(2), 190-197.

Tyner, J., \& Inwood, J. (2014). Violence as fetish: Geography, Marxism, and dialectics. Progress in Human Geography, 38(6), 771-784.

UNODC. (2013). World Drug Report 2013. New York: United Nations Office on Drugs and Crime.

Wilding, P. (2016). Crossing disciplinary, empirical and theoretical boundaries on gender and violence. Dialogues 
in Human Geography, 6(2), 198-201.

Wright, M. W. (2004). From protests to politics: Sex work, women's worth, and ciudad Juárez modernity. Annals of the Association of American Geographers, 94(2), 369-386. 